\title{
Techno-Economic Feasibility Analysis of Hybrid Systems for Decentralized Power Generation in India
}

\author{
Sheeraz Kirmani, Mohd Shadab \\ Department of Electrical Engineering, Faculty of Engineering \&Technology, Jamia Millia Islamia, New Delhi, India
}

Email address:

sheerazkirmani@gmail.com (S. Kirmani), logontoraza@gmail.com (M. Shadab)

To cite this article:

Sheeraz Kirmani, Mohd Shadab. Techno-Economic Feasibility Analysis of Hybrid Systems for Decentralized Power Generation in India. International Journal of Energy and Power Engineering. Vol. 4, No. 2, 2015, pp. 103-117. doi: 10.11648/j.ijepe.20150402.21

\begin{abstract}
The main objective of this paper is to find the optimum configuration from amongst the different combination of hybrid energy systems that will fulfill the electrical energy requirement of selected village reliably and economically. The various systems that are considered are solar-grid connected system, solar-diesel system, solar-wind energy system, wind-grid connected system, solar-wind-grid connected system, wind-diesel-grid connected system and solar-diesel-grid connected system. The comparison of these systems is done based on various economic indicators like internal rate of return, net present cost, payback period and cost of energy. From amongst the various systems that have been considered in this study wind-grid connected system is best suited hybrid system for the considered case having lowest cost of energy as Rs. 2.34/kWh. Also the initial cost of this system is less in comparison to other hybrid systems considered.
\end{abstract}

Keywords: Hybrid Energy Systems, Techno-Economic Analysis, Decentralized Power Generation

\section{Introduction}

Electricity is one of the driving forces in a growing economy and increasing demand puts incredible pressure on the countries energy infrastructure to match that demand. India as a developing country, where majority of the population lives in rural areas without access to electricity, the problem therefore assumes greater importance. Extension of the central electricity grid to such areas is either financially not viable or practically not feasible as these locations are geographically isolated, sparsely populated and have a very low power demand.

In India, out of 593,732 villages there are 21,318 villages listed under the category of un-electrified villages as per ministry of new and Renewable energy Sources, Government of India. Electrification of the unelectrified villages is a great challenge facing the developing countries including India. The Government of India has taken essential steps towards the implementation and promotion of decentralized electricity generation through Renewable Energy Technology (RET) systems. At present in most of the unelectrified villages in India that are located far away from the central electricity grid and have small loads are supplied traditionally by diesel generators which have high reliability, high running cost, high maintenance and low efficiency. However these locations normally called as remote areas present a significant potential market for renewable energy based systems like solar and wind. Moreover, from an environmental perspective renewable energy system are sustainable and environment friendly.

A.H. Al-Badi et al [1] have done the study to determine the optimum size of systems able to fulfill the electrical energy requirements of remote sites located in the South of Oman. The methodology applied provides a useful and simple approach for sizing and analyzing the hybrid systems which can provide the required electricity reliably and economically. The results of the analysis are a list of feasible power supply systems, classified according to their net present cost. The energy management of hybrid energy systems taking life cycle cost into account is discussed [2-4]. The simulation result of different combinations of hybrid energy systems in grid connected and standalone mode is analyzed to find out the most cost effective system. Photovoltaic panels, wind turbines, diesel generators and grid connection are used as the energy sources in this study. As hybrid system of minimum two and maximum three sources are considered, reliability of the system increased. The combinations used are PV-Wind-Diesel, PV-Grid, Wind-Grid, PV-Wind and PVWind-Grid. The possibility of wind alone, PV alone and hybrid wind/PV system for a typical residential load in Montana is discussed [5]. Generation and storage units for 
different system are properly sized in order to meet the annual load and minimize the total annual cost to the customer. In addition, an economic analysis has been performed for the three different scenarios and is used to justify the use of renewable energy versus constructing a line extension from the nearest existing power line to supply the load with conventional power.

Annual average hourly values for load, wind speed, and insolation have been used. This work takes into account the economic factors for calculation of optimum component size.

An economic analysis is performed for realizing the advantage of the stand-alone system versus constructing a line extension from the nearest existing distribution line for supplying the load with conventional power. The sizing and techno-economic optimization of an autonomous hybrid $\mathrm{PV} /$ Wind energy system with battery storage is discussed [5]. The study has considered the various aspects e.g. the level of autonomy i.e. the fraction of time for which the specified load can be met and the cost of the system rather than designing the system for the worst month scenario which lead too costly system as done by few researchers the system cost and performance both are taken into account and a third energy source that is a battery is connected in the system to reduce the cost. Similarly, optimization of unit sizing of various combinations of hybrid energy system is also reported [6-8]. Similarly [9-10] presents the economic analysis of various combinations of hybrid systems under different operating conditions and [11] presents technoeconomic comparison of various energy supplying systems. From the literature, it is found that it is very essential to develop an algorithm for optimal operation of hybrid energy system especially for Indian scenario, which can be applied to any type and any number of systems.

In this paper, an optimal operating strategy for hybrid energy system is proposed. the simulation result of different combinations of hybrid energy systems with and without grid is analyzed to find out the most cost effective system. Photovoltaic panels, wind turbines, diesel generators and grid connection are used as the energy sources in this purpose. As hybrid system of minimum two and maximum three sources are considered, reliability of the system increased. The combinations used are PV-Wind-Diesel, PV-Grid, Wind-Grid, PV-Wind and PV- Wind-Grid.

\section{Description of the Area Considered for Electrification and Metrological Data}

The optimal installation sites for the hybrid systems are characterized by good average renewable energy resource potential. After preliminary study, it was observed that the site selected in this case study has good solar as well as wind potential. Therefore this site is chosen for this case study. For this hybrid system, the meteorological data of Solar
Radiation, monthly wind speed are taken for the village Rawra in Udaipur, Rajasthan (latitude and longitude of the site is $26.238^{\circ} \mathrm{N} \& 73.0243^{\circ} \mathrm{E}$ respectively). The population of village is about 890 and peak load taken is $51 \mathrm{~kW}$. Daily solar radiation data were imported into HOMER to calculate daily radiation and monthly average values of clearness index. These data were taken from Indian meteorological department. The average clearness index is 0.68 and average daily radiation is $5.53 \mathrm{KWh} / \mathrm{m}^{2} /$ day. Figure 1 shows the variation of solar radiation.

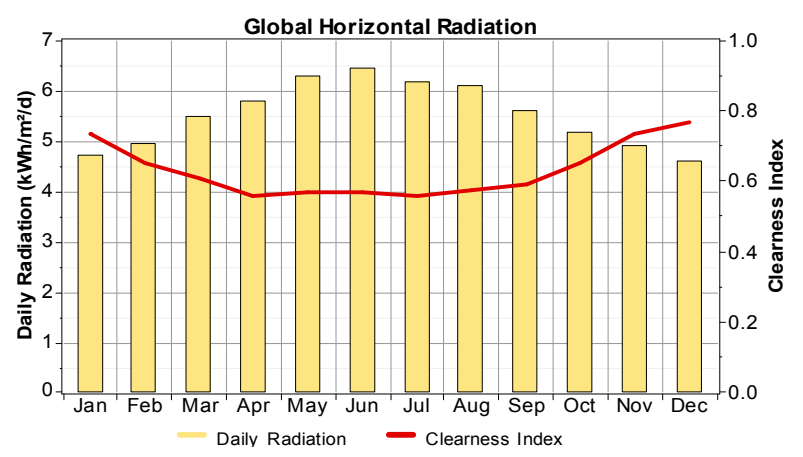

Figure 1. Daily solar radiation with clearness index.

Wind speed also varies seasonally. Average wind speed at the selected site is $4.117 \mathrm{~ms}^{-1}$. This data were collected from India Meteorological Department. Figure. 2 shows the monthly wind speed variation.

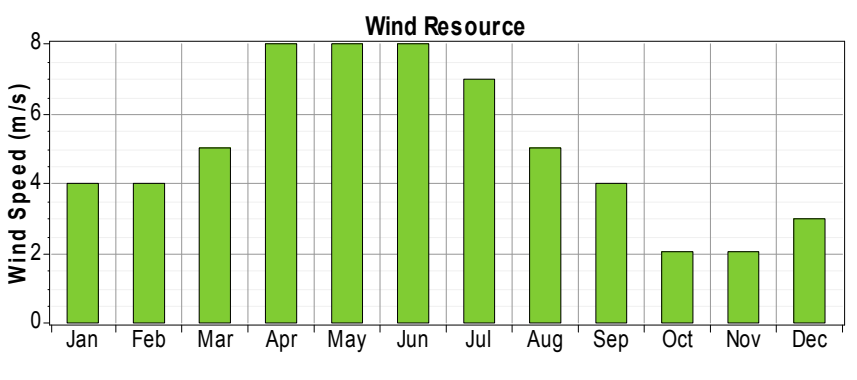

Figure 2. Monthly wind speed variations.

The proposed hybrid power system is designed to ensure the reliable and economic electric supply to the village. The village requires a maximum of $51 \mathrm{~kW}$ peak demand and it has a base demand of approximately $30 \mathrm{~kW}$. From the load profile, it can be seen that, during night times, the load requirements are the lowest since that is the off working hours of the staffs and students. The maximum demand occurs during daytime from 2 p.m. to 2 a.m. during January and from 2 p.m. to 4 a.m. during July period. The peak demand is about $30 \mathrm{~kW}$ in January and peak demand is about $51 \mathrm{~kW}$ in July. Figure 4 illustrates the average and the deviation of the monthly load profile for the site. The scaled annual average energy demand of the studied building as simulated by HOMER software is $722 \mathrm{kWh} /$ day. 


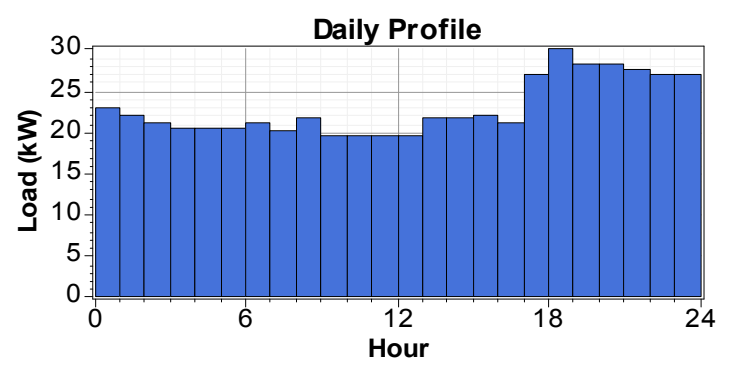

(a) Hourly Load Profile for January

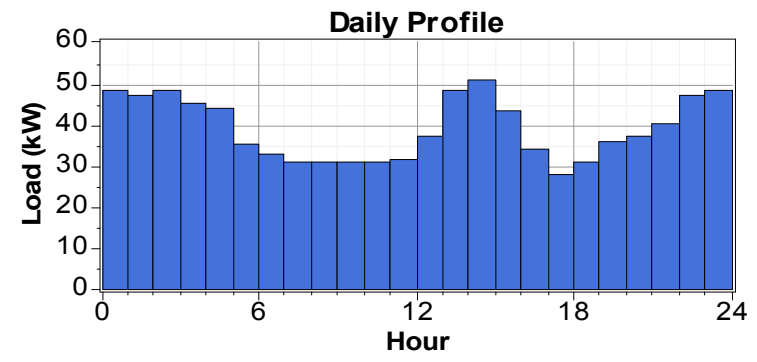

(b) Hourly Load Profile for July

Figure 3. Daily Load Profile for (a) January \& (b) July.

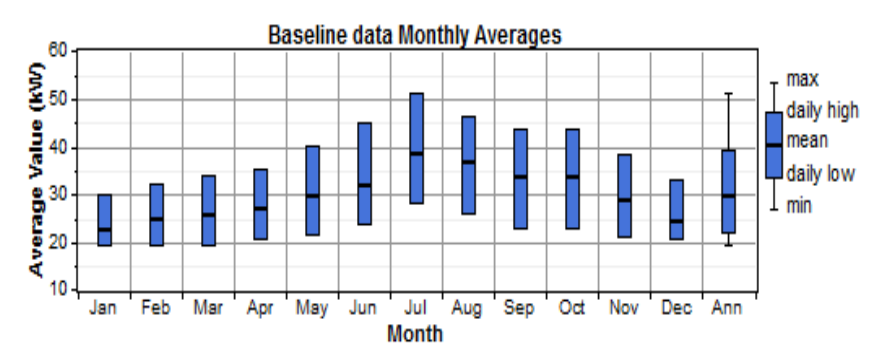

Figure 4. Monthly load profile.

\section{Hybrid System Design and Analysis}

The Hybrid Optimization Model for Electric Renewables (HOMER) is used in this work, it is used to model a power system physical behavior and its life-cycle cost, which is the total cost of installing and operating the system over its life time.

\subsection{Simulation}

The simulation process determines how a particular system configuration, a combination of system components of specific sizes, and an operating strategy that defines how those components work together, would behave in a given setting over a long period of time.

The system can be grid-connected or autonomous and can serve ac and dc electric loads and a thermal load. Systems that contain a battery bank and one or more generators require a dispatch strategy, which is a set of rules governing how the system charges the battery bank. The simulation process serves two purposes. First, it determines whether the system is feasible. The feasible system is one which can adequately serve the electric and thermal loads and satisfy any other constraints imposed by the user. Second, it estimates the life-cycle cost of the system, which is the total cost of installing and operating the system over its lifetime. The lifecycle cost is a convenient metric for comparing the economics of various system configurations.

\subsection{Optimization}

The simulation process models a particular system configuration, whereas the optimization process determines the best possible system configuration. The best possible, or optimal, system configuration is the one that satisfies the user-specified constraints at the lowest total net present cost. Finding the optimal system configuration may involve deciding on the mix of components that the system should contain, the size or quantity of each component, and the dispatch strategy the system should use. In the optimization process, many different system configurations are simulated; the infeasible ones are discarded, the feasible ones are ranked according to total net present cost, and the feasible one is presented with the lowest total net present cost as the optimal system configuration.

The goal of the optimization process is to determine the optimal value of each decision variable that interests the modeler. A decision variable is a variable over which the system designer has control and for which multiple possible values can be considered in the optimization process. Pos sible decision variables include: the size of the PV array, the number of wind turbines, the size of each generator, the number of batteries, the size of the dc-ac converter, the dispatch strategy.

\subsection{Sensitivity Analysis}

In the sensitivity analysis process multiple optimizations are performed, each using a different set of input assumptions. A sensitivity analysis reveals how sensitive the outputs are to changes in the inputs.

In a sensitivity analysis, a range of values for a single input variable are fed to HOMER. A variable for which the user has entered multiple values is called a sensitivity variable. Almost every numerical input variable that is not a decision variable can be a sensitivity variable. Examples include the PV module price, the fuel price, the interest rate, etc.

\subsection{Economic Analysis}

The economic study is based on a financial evaluation of different configuration of hybrid systems based on renewable energy technologies (T C Kandpal et.al 2003). The different parameters that are calculated for comparing the various systems are payback period, internal rate of return (IRR), net present cost (NPC) and cost of energy (COE),

\subsection{Payback Period}

It is the time in which initial investment is expected to recover from the cash inflow generated by the investment. It 
can be calculate by the expression (1)

$$
-I C+\sum_{n=1}^{p} \frac{\mathrm{QN}}{\left((1+i)^{n}\right)}
$$

Where IC is the initial cost, $\mathrm{QN}$ is net cash flow, ' $\mathrm{i}$ ' is the rate of interest and $\mathrm{P}$ is the payback period.

\subsubsection{R. R (Internal Rate of Return)}

The internal rate of return on an investment or project is the "annualized effective compounded return rate" that makes the net present value (NPV) equal to zero.

$$
N P V=\sum_{n=0}^{N} \mathrm{Cn} /(1+r)^{n}=0
$$

$\mathrm{Cn}$ is cash flow, $\mathrm{r}$ is internal rate of return and $\mathrm{n}$ is the positive integer.

\subsubsection{Net Present Cost (NPC)}

The quantity used to represent the life-cycle cost of the system is the total net present cost (NPC). This single value includes all costs and revenues that occur within the project lifetime, with future cash flows discounted to the present. The total net present cost includes the initial capital cost of the system components, the cost of any component replacements that occur within the project lifetime, the cost of maintenance and fuel.

The net present value of the system can be calculated with the formula

$$
\mathrm{NPC}=-\mathrm{C}_{\mathrm{o}}+(\mathrm{B}-\mathrm{C}) \sum_{\mathrm{t}=1}^{\mathrm{T}}\left(\left[1+\frac{\mathrm{d}}{10 \phi}\right]^{-\mathrm{t}}+\mathrm{L}_{\mathrm{T}}\left[1+\left(\frac{\mathrm{d}}{100}\right)\right]^{-\mathrm{t}}\right)
$$

Where $\mathrm{Co}=$ initial investment, $\mathrm{B}=$ annual benefits, $\mathrm{C}=$ annual investment, $\mathrm{d}=$ discount rate, $\mathrm{t}=$ time period. From among the mutually exclusive events the project which has got maximum positive NPC is economically more feasible. Table 1 shows the economic and technical specifications for the components of the proposed hybrid energy system.

\subsubsection{Cost of Energy}

The unit electrical cost can be calculated using the relation

$$
\text { The per unit cost of energy }=\frac{\mathrm{ALCC}}{365 \times \mathrm{E}_{\mathrm{L}}}
$$

Where ALCC is the annualized life cycle cost, EL is the average daily load demand.

\subsection{PV and Grid Connected System}

Figure 5 shows the PV and grid connected system configuration as designed in Homer simulation software.

Figure 6 shows the HOMER output results ordered from lowest NPC for adding the PV generation system to the simulation. HOMER uses the total NPC as its main selection tool.

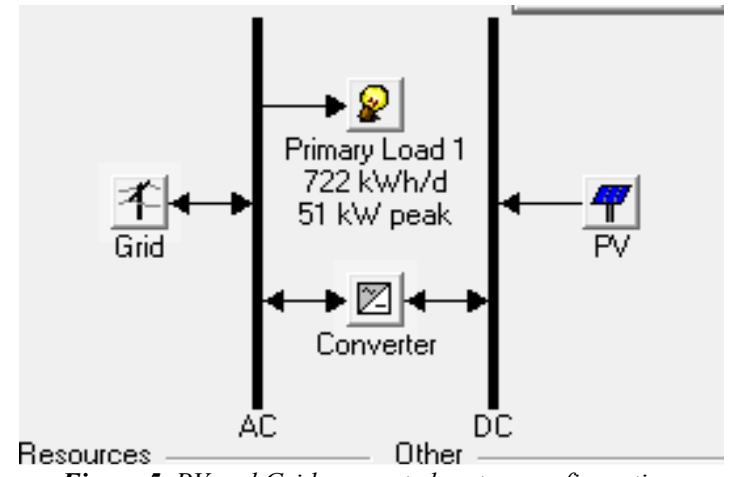

\begin{tabular}{|c|c|}
\hline Description & Data \\
\hline \multicolumn{2}{|l|}{ PV } \\
\hline Capital cost & $99,990 \mathrm{Rs} / \mathrm{kW}$ \\
\hline Lifetime & 25 years \\
\hline Operation and maintenance cost & $550 \mathrm{Rs} / \mathrm{kW} /$ year \\
\hline Replacement cost & $99,990 \mathrm{Rs} / \mathrm{kW}$ \\
\hline \multicolumn{2}{|l|}{ Diesel generator } \\
\hline Capital cost & $13,750 \mathrm{Rs} / \mathrm{kW}$ \\
\hline Rated power & Variable $(0-500 \mathrm{~kW})$ \\
\hline Minimum allowed power (min load ratio) & $30 \%$ of rated power \\
\hline Operation and maintenance cost & $1 \mathrm{Rs} / \mathrm{h} / \mathrm{kW}$ \\
\hline Operating hours & $15,000 \mathrm{~h}$ \\
\hline Replacement cost & $13,750 \mathrm{Rs} / \mathrm{kW}$ \\
\hline \multicolumn{2}{|l|}{ Wind turbine } \\
\hline Capital cost & Rs. 1320000 \\
\hline Lifetime & 25 years \\
\hline Rated power & $25 \mathrm{~kW} \mathrm{AC}$ \\
\hline Operation and maintenance cost & $2706 \mathrm{Rs} / \mathrm{kW} /$ year \\
\hline Replacement cost & Rs 407040 \\
\hline Cut in wind speed & $3.5 \mathrm{~m} / \mathrm{s}$ \\
\hline High cut-out wind speed & $25 \mathrm{~m} / \mathrm{s}$ \\
\hline Hub height & $25 \mathrm{~m}$ \\
\hline \multicolumn{2}{|l|}{ Batteries } \\
\hline Type of batteries & Surrette 6CS25P \\
\hline Nominal voltage $(\mathrm{V})$ & $6 \mathrm{~V}$ \\
\hline Nominal capacity & $1,156 \mathrm{Ah}$ \\
\hline Nominal energy capacity of each battery & $6.94 \mathrm{kWh}$ \\
\hline Operation and maintenance cost & $110 \mathrm{Rs} /$ year \\
\hline Capital cost & $6,875 \mathrm{Rs}$ \\
\hline Replacement cost & $2,750 \mathrm{Rs}$ \\
\hline \multicolumn{2}{|l|}{ Converter } \\
\hline Capital cost & $36,025 \mathrm{Rs} / \mathrm{kW}$ \\
\hline Operation and maintenance cost & $110 \mathrm{Rs} /$ year/kW \\
\hline Lifetime & 15 years \\
\hline Replacement cost & $36,025 \mathrm{Rs} / \mathrm{kW}$ \\
\hline Efficiency & $95 \%$ \\
\hline Project life time & 25 years \\
\hline
\end{tabular}

Figure 5. PV and Grid connected system configuration.

Table 1. Economic and technical specification for the components of the proposed hybrid energy system.

\subsubsection{Sensitivity Analysis of PV and Grid Connected System}

Figure 6 shows the sensitivity results of PV and grid connected system given by the HOMER. We can see that there is only one optimal system with a PV system. This 
system has a PV fraction of $4 \%$ with a grid fraction of $96 \%$. For the optimal alternative system, the PV system and inverter size are $5 \mathrm{KW}$

Details of this configuration are shown in Table 2 The total NPC, Initial Capital cost and COE for such a hybrid system are Rs 30588300, Rs 2609520 and Rs 8.22/kWh, respectively.

Figure 7 shows the monthly distribution of the electricity produced in $\mathrm{kW}$ by the Solar PV and Grid. The effect of SPV penetration reduces the energy consumption from grid.

Min. Ren. Fraction $(\%) 18 \quad \square$

Double cick on a system below for simulation results.

\begin{tabular}{|c|c|c|c|c|c|c|c|c|c|c|}
\hline & $\begin{array}{l}\mathrm{PV} \\
\mathrm{kW}\end{array}$ & $\begin{array}{l}\text { Conv. } \\
\text { (kW) }\end{array}$ & $\begin{array}{l}\text { Gind } \\
(\mathrm{kW})\end{array}$ & $\begin{array}{l}\text { Intial } \\
\text { Captal }\end{array}$ & $\begin{array}{l}\text { Operating } \\
\left.\text { Cost }(\$ / y)^{2}\right)\end{array}$ & $\begin{array}{l}\text { Total } \\
\text { NPC }\end{array}$ & $\left|\begin{array}{c}C O E \\
(S / k W h)\end{array}\right|$ & $\begin{array}{c}\text { Net Purchases } \\
(\mathrm{kWh} / \mathrm{y})\end{array}$ & $\begin{array}{l}\text { Ren. } \\
\text { Frac. }\end{array}$ & $\begin{array}{l}\text { Capacty } \\
\text { Shortage }\end{array}$ \\
\hline & 30 & 20 & 35 & $\$ 62,010$ & 34,899 & $\$ 553.869$ & 0.155 & 207,339 & 0.18 & 0.07 \\
\hline & 30 & 30 & 35 & $\$ 68,010$ & 34,965 & $\$ 560,808$ & 0.157 & 206,463 & 0.19 & 0.07 \\
\hline & 30 & 40 & 35 & $\$ 74,010$ & 35,148 & $\$ 569,386$ & 0.159 & 206.463 & 0.19 & 0.07 \\
\hline & 30 & 50 & 35 & $\$ 80,010$ & 35,331 & $\$ 577,963$ & 0.161 & 206,463 & 0.19 & 0.07 \\
\hline & 40 & 30 & 35 & $\$ 84,680$ & 35.250 & $\$ 581,485$ & 0.161 & 191,070 & 0.25 & 0.06 \\
\hline & 40 & 20 & 35 & $\$ 78,680$ & 36,014 & $\$ 586,255$ & 0.164 & 198,210 & 0.22 & 0.06 \\
\hline & 30 & 60 & 35 & $\$ 86,010$ & 35.514 & $\$ 586,541$ & 0.164 & 206,463 & 0.19 & 0.07 \\
\hline & 40 & 40 & 35 & $\$ 90,680$ & 35,406 & $\$ 589,695$ & 0.163 & 190,874 & 0.25 & 0.06 \\
\hline & 30 & 70 & 35 & $\$ 92,010$ & 35,697 & $\$ 595,118$ & 0.166 & 206,463 & 0.19 & 0.07 \\
\hline & 40 & 50 & 35 & $\$ 96,680$ & 35,589 & $\$ 598,273$ & 0.166 & 190,874 & 0.25 & 0.06 \\
\hline & 30 & 80 & 35 & $\$ 98.010$ & 35,880 & $\$ 603,695$ & 0.169 & 206,463 & 0.19 & 0.07 \\
\hline & 40 & 60 & 35 & $\$ 102,680$ & 35,772 & $\$ 606,850$ & 0.168 & 190,874 & 0.25 & 0.06 \\
\hline & 50 & 30 & 35 & $\$ 101,350$ & 35.949 & $\$ 608,018$ & 0.167 & 178,810 & 0.29 & 0.06 \\
\hline & 50 & 40 & 35 & $\$ 107,350$ & 35,659 & $\$ 609,926$ & 0.166 & 175.242 & 0.30 & 0.06 \\
\hline & 40 & 70 & 35 & $\$ 108,680$ & 35.955 & $\$ 615,427$ & 0.170 & 190,874 & 0.25 & 0.06 \\
\hline & 50 & 50 & 35 & $\$ 113,350$ & 35,837 & $\$ 618,438$ & 0.168 & 175,207 & 0.30 & 0.06 \\
\hline & 40 & 80 & 35 & $\$ 114,680$ & 36.138 & $\$ 624,005$ & 0.173 & 190.874 & 0.25 & 0.06 \\
\hline & 50 & 20 & 35 & $\$ 95,350$ & 37,613 & $\$ 625,470$ & 0.175 & 192,733 & 0.24 & 0.06 \\
\hline & 50 & 60 & 35 & $\$ 119,350$ & 36,020 & $\$ 627,016$ & 0.171 & 175.207 & 0.30 & 0.06 \\
\hline & 60 & 40 & 35 & $\$ 124,020$ & 36,131 & $\$ 633,248$ & 0.169 & 161,263 & 0.35 & 0.06 \\
\hline & 50 & 70 & 35 & $\$ 125,350$ & 36,203 & $\$ 635,593$ & 0.173 & 175,207 & 0.30 & 0.06 \\
\hline & 60 & 50 & 35 & $\$ 130,020$ & 36,082 & $\$ 638,558$ & 0.169 & 159.516 & 0.35 & 0.06 \\
\hline
\end{tabular}

Figure 6. The overall optimization results from HOMER.

\subsubsection{Emissions for PV and Grid Connected System}

In India, the main source of power generation is coal based power plants. As a consequence in 2010-2012, its emission factor for the electricity sector was $0.81 \mathrm{~kg} \mathrm{CO}_{2} / \mathrm{kWh}$.

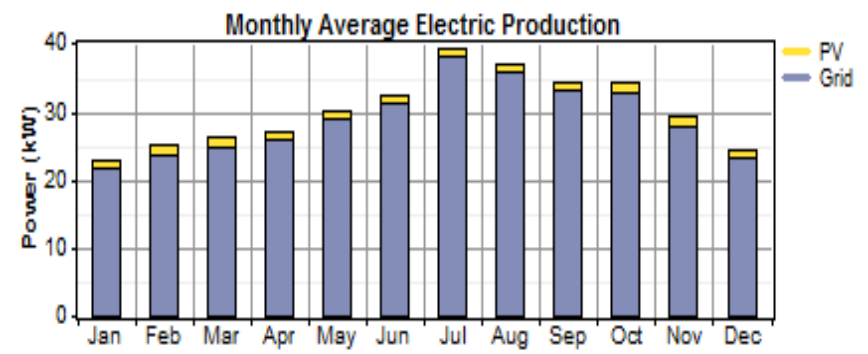

Figure 7. Monthly average electricity production from $P V$ and grid connected system.

Table 2. Technical \& Cost details of the best suited PV and Grid configuration for hybrid system.

\begin{tabular}{|c|c|c|c|c|c|c|}
\hline \multicolumn{2}{|l|}{ Cost summary } & \multicolumn{2}{|c|}{ System Architecture } & \multicolumn{3}{|l|}{ Electrical } \\
\hline Total net present cost & Rs 30588300 & PV Array & $5 \mathrm{~kW}$ & Component & Production & Froction \\
\hline Levelized cost of energy & Rs $8.22 / \mathrm{kWh}$ & Grid & $51 \mathrm{~kW}$ & Component & $(\mathrm{kWh} / \mathrm{yr})$ & Fraction \\
\hline Operating cost & Rs $2114940 / y r$ & Inverter & $5 \mathrm{~kW}$ & PV Array & 10,500 & $4 \%$ \\
\hline \multirow[t]{2}{*}{ Reliability } & $93 \%$ & Rectifier & $5 \mathrm{~kW}$ & Grid & 254,081 & $96 \%$ \\
\hline & & Dispatch Strategy & Load Following & Total & 264,581 & $100 \%$ \\
\hline
\end{tabular}

Table 3 shows the types of GHG and other emission and their quantity given out by the PV and grid connected system over one year in operation when PV penetration is $4 \%$ and $20 \%$ respectively. We can see that the emissions are reduces significantly as the PV penetration increases.

Table 3. GHG \& emissions recorded from the HOMER analysis for PV and grid connected system when PV penetration is $4 \%$ and $20 \%$ respectively.

\begin{tabular}{llll}
\hline Pollutant & Emissions $(\mathbf{k g} / \mathbf{y r})$ & Pollutant & Emissions $(\mathbf{k g} / \mathbf{y r})$ \\
\hline Carbon dioxide & $1,60,579$ & Carbon dioxide & $1,31,039$ \\
Carbon monoxide & 0 & Carbon monoxide & 0 \\
Unburned hydrocarbons & 0 & Unburned hydrocarbons & 0 \\
Particulate matter & 0 & Particulate matter & 0 \\
Sulfur dioxide & 696 & Sulfur dioxide & 568 \\
Nitrogen oxides & 2,208 & Nitrogen oxides & 278 \\
\hline
\end{tabular}




\subsection{PV, Diesel and Grid Based System}

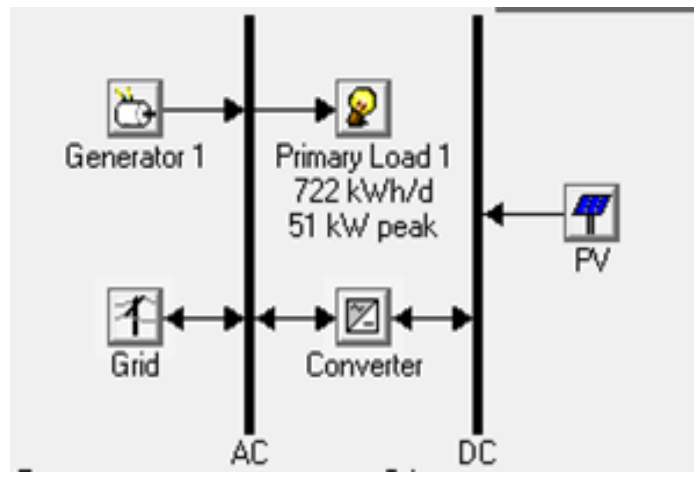

Figure 8. PV, Diesel and Grid based system configuration.
Figure 8 shows the PV and diesel based system configuration as designed in Homer simulation software. For the off-grid electrification, various combinations have been obtained of hybrid systems with SPV, diesel generator, batteries and convertors from the HOMER Optimization simulation software.

All the possible hybrid system configurations are listed in ascending order of their total NPC in the figure shown below. The technical and economical details of all the configurations of the hybrid systems from the optimization process are shown in detail in Figure 9, where the best possible combination of SPV, a diesel generator and Grid is on top of the Figure. The upper most combination is able to fully meet the load demands at the lowest possible total NPC.

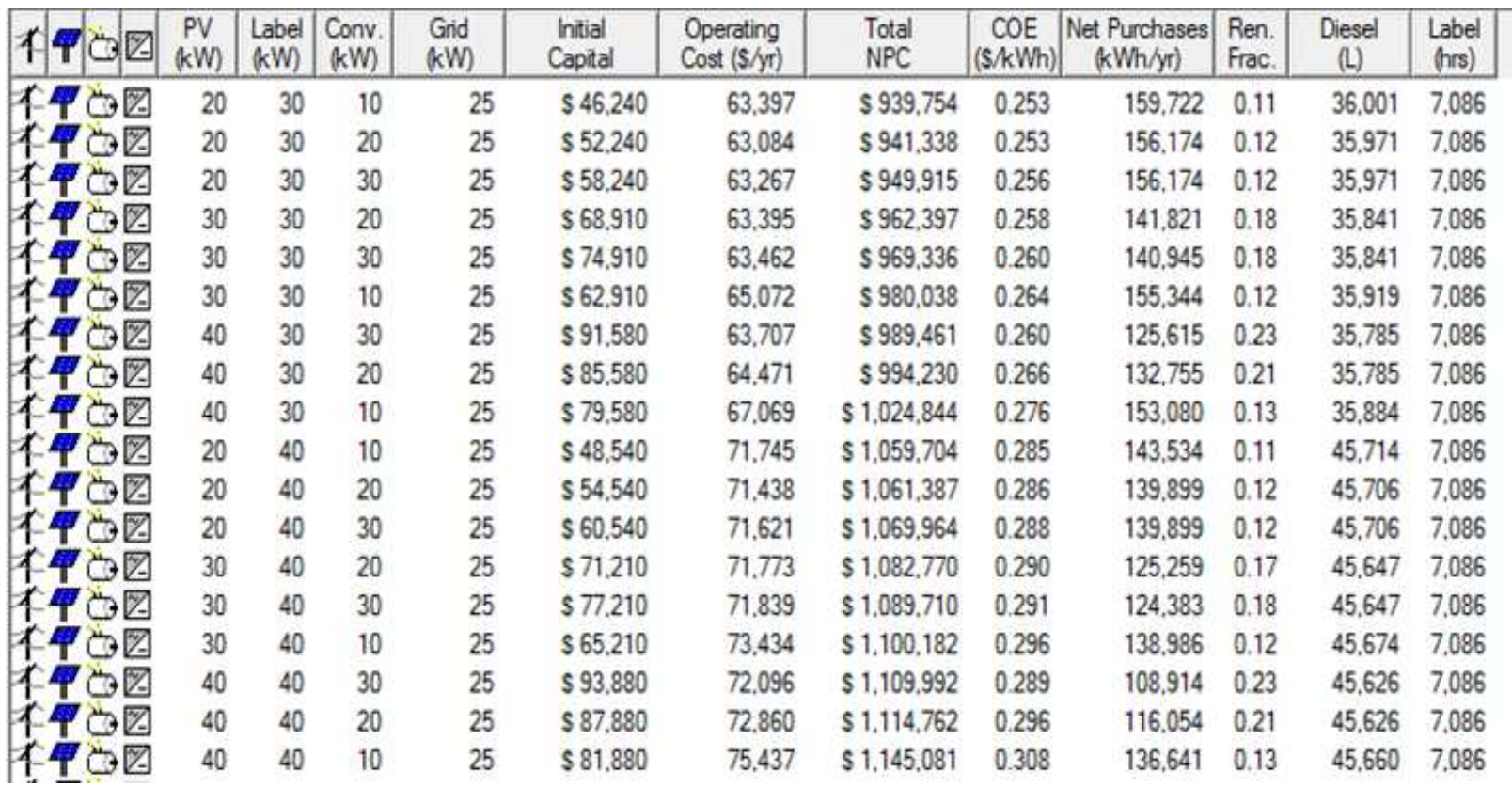

Figure 9. Optimization results for PV, Diesel and Grid based system.

According to the optimization results, the optimal combination of hybrid system components are a $20 \mathrm{~kW} \mathrm{PV-}$ Array, $30 \mathrm{~kW}$ Diesel Generator, $25 \mathrm{~kW}$ from grid, $20 \mathrm{~kW}$ Inverter and a $20 \mathrm{~kW}$ Rectifier with a dispatch strategy of load following. Details of this configuration are shown in Table 4. The total NPC, operating cost and Levelized cost of energy (COE) for such a hybrid system are Rs 56385240, 3803820 and Rs 15.18/kWh, respectively.

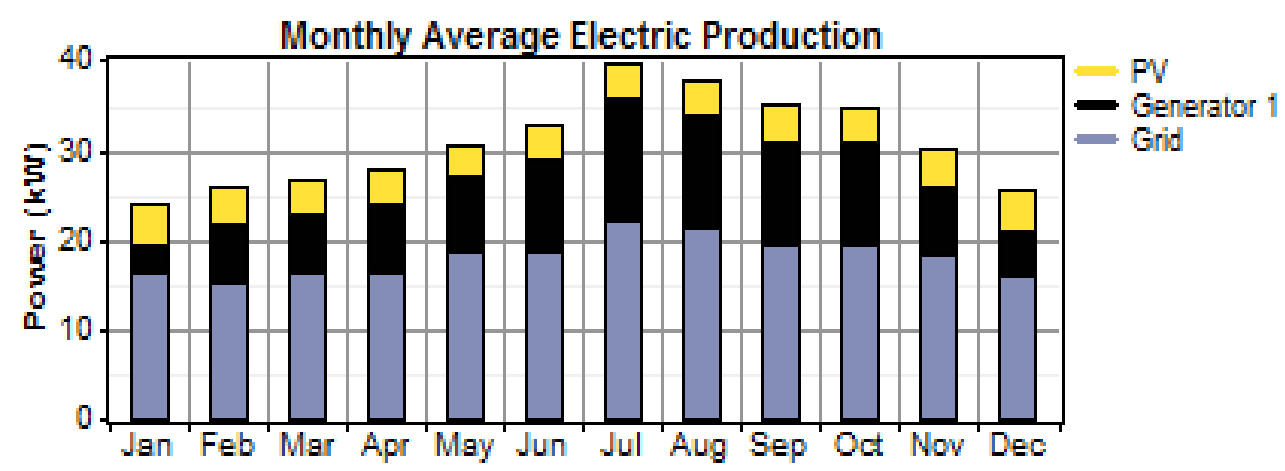

Figure 10. Monthly average electricity production for PV, diesel and Grid based system.

Figure 10 shows the monthly distribution of the electricity produced in $\mathrm{kW}$ by the SPV, Diesel generator and grid. The effect of SPV penetration reduces the diesel fuel consumption. As the output from the PV increases, the 
generator's operation hours decrease.

Table 4. Technical \& Cost details of the best suited configuration for PV, Diesel and Grid based system.

\begin{tabular}{|c|c|c|c|c|c|c|}
\hline \multicolumn{2}{|l|}{ Cost summary } & \multicolumn{2}{|c|}{ System Architecture } & \multicolumn{3}{|l|}{ Electrical } \\
\hline Total net present cost & Rs56385240 & PV Array & $20 \mathrm{~kW}$ & \multirow{2}{*}{ Component } & \multirow{2}{*}{$\begin{array}{l}\text { Production } \\
(\mathrm{kWh} / \mathrm{yr})\end{array}$} & \multirow{2}{*}{ Fraction } \\
\hline Levelized cost of energy & Rs15.18/kWh & Diesel Generator & $30 \mathrm{~kW}$ & & & \\
\hline Operating cost & Rs3803820/yr & Grid & $25 \mathrm{~kW}$ & Grid & 159,722 & $59 \%$ \\
\hline \multirow[t]{3}{*}{ Reliability } & $100 \%$ & Inverter & $20 \mathrm{~kW}$ & PV Array & 35,000 & $13 \%$ \\
\hline & & Rectifier & $20 \mathrm{~kW}$ & Diesel Generator & 75,976 & $28 \%$ \\
\hline & & & & Total & 270,698 & $100 \%$ \\
\hline
\end{tabular}

Table 5. Annualized Cost of the PV, Diesel and Grid based system.

\begin{tabular}{lllllll}
\hline Component & Capital (Rs/yr) & Replacement (Rs/yr) & O\&M (Rs /yr) & Fuel (Rs /yr) & Salvage (Rs/yr) & Total(Rs /yr) \\
\hline PV & 2,366 & 758 & 4,340 & 0 & -445 & 7,018 \\
Generator & 490 & 3,055 & 3,614 & 28,801 & -27 & 35,932 \\
Grid & 0 & 0 & 19,205 & 0 & 0 & 19,205 \\
Converter & 426 & 205 & 20 & 0 & -42 & 609 \\
Other & 0 & 0 & 3,915 & 0 & 0 & 3,915 \\
System & 3,281 & 4,018 & 31,093 & 28,801 & -515 & 66,678 \\
\hline
\end{tabular}

Table 5 shows the annualized cost of the proposed system's components. It can be seen that the costs for the DG and SPV are distributed completely oppositely over both components' lifespan: The capital cost of the Diesel generator makes up only $5 \%$ of the system's total capital cost, whereas almost $60 \%$ of the initial investment go to the SPV arrays. Once installed, however, SPV is cheap to maintain and operate compared to DG, which in the end is responsible for $59.5 \%$ of the system's total annual cost of Rs 29425110 .

Emissions for PV, Diesel and Grid Based System

Table 6 shows the types of GHG and other emission and their quantity given out by the PV and diesel based system over one year in operation.

Table 6. GHG \& emissions recorded from the HOMER analysis for PV, diesel and Grid based system.

\begin{tabular}{ll}
\hline Pollutant & Emissions $(\mathbf{k g} / \mathbf{y r})$ \\
\hline Carbon dioxide & 195,747 \\
Carbon monoxide & 234 \\
Unburned hydrocarbons & 25.9 \\
Particulate matter & 17.6 \\
Sulfur dioxide & 628 \\
Nitrogen oxides & 2,302 \\
\hline
\end{tabular}

\subsection{PV, Wind and Diesel Connected System with Batteries}

Figure 11 shows the PV, Wind and diesel based system configuration as designed in Homer simulation software.

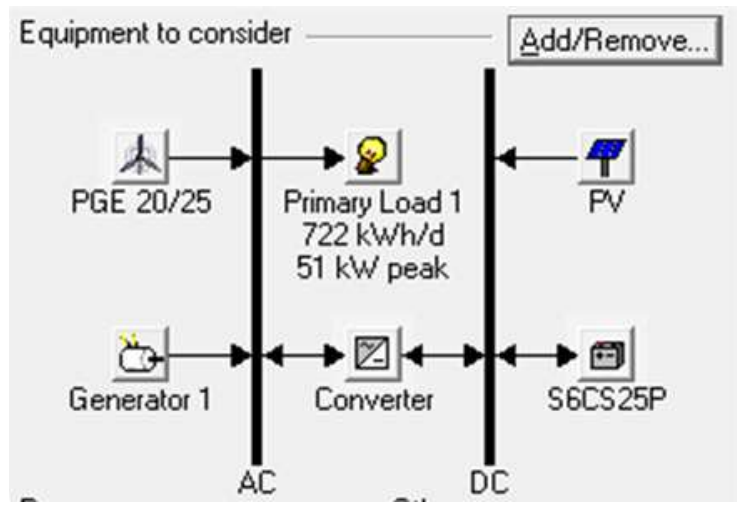

Figure 11. PV, Diesel and Grid connected system configuration.

The optimization results of $\mathrm{PV}$, diesel and Wind based system with batteries are shown in Figure 12. All the possible hybrid system configurations are listed in ascending order of their total NPC in the figure shown below. 


\begin{tabular}{|c|c|c|c|c|c|c|c|c|c|c|c|c|c|}
\hline \multicolumn{14}{|c|}{ ouble click on a system below for simulation results. } \\
\hline 雨人四国 & $\begin{array}{l}\mathrm{PV} \\
(\mathrm{kW})\end{array}$ & PGE25 & $\begin{array}{l}\text { Label } \\
\text { (kW) }\end{array}$ & S6CS25P & $\begin{array}{l}\text { Conv. } \\
\text { (kW) }\end{array}$ & $\begin{array}{l}\text { Initial } \\
\text { Capital }\end{array}$ & $\begin{array}{l}\text { Operating } \\
\text { Cost (S/yr) }\end{array}$ & $\begin{array}{l}\text { Total } \\
\text { NPC }\end{array}$ & $\begin{array}{c}\mathrm{COE} \\
(\mathrm{S} / \mathrm{kWh})\end{array}$ & $\begin{array}{l}\text { Ren. } \\
\text { Frac. }\end{array}$ & $\begin{array}{l}\text { Diesel } \\
\text { (L) }\end{array}$ & $\begin{array}{l}\text { Label } \\
\text { (hrs) }\end{array}$ & \begin{tabular}{|c|}
$\begin{array}{c}\text { Batt. If. } \\
(y r)\end{array}$ \\
\end{tabular} \\
\hline 雨日四 & 5 & 3 & 50 & 25 & 20 & $\$ 129.085$ & 46.227 & $\$ 780.605$ & 0.210 & 0.63 & 37.519 & 3.307 & 12.0 \\
\hline 中人见円 & 6 & 3 & 50 & 25 & 20 & $\$ 130,752$ & 46.207 & $\$ 781.994$ & 0.211 & 0.63 & 37,258 & 3.289 & 12.0 \\
\hline$\theta$ & 5 & 3 & 50 & 20 & 20 & \$ 122.835 & 46.856 & $\$ 783.219$ & 0.211 & 0.63 & 38.277 & 3.446 & 12.0 \\
\hline 용 & 6 & 3 & 50 & 20 & 20 & \$ 124,502 & 46.822 & $\$ 784,404$ & 0.211 & 0.63 & 38.008 & 3,423 & 12.0 \\
\hline$\theta \square$ & 5 & 3 & 50 & 30 & 20 & \$ 135,335 & 46.103 & s 785.112 & 0.211 & 0.63 & 37,208 & 3.245 & 12.0 \\
\hline 图 & 5 & 3 & 51 & 25 & 20 & $\$ 129.315$ & 46.552 & \$ 785,419 & 0.211 & 0.63 & 37.788 & 3.306 & 12.0 \\
\hline (1) & 6 & 3 & 51 & 25 & 20 & $\$ 130,982$ & 46.538 & $\$ 786.892$ & 0.212 & 0.63 & 37.532 & 3.289 & 12.0 \\
\hline 3 & 6 & 3 & 50 & 30 & 20 & \$ 137,002 & 46.134 & \$ 787.208 & 0.212 & 0.63 & 36.990 & 3.235 & 12.0 \\
\hline 因图 & 5 & 3 & 51 & 20 & 20 & $\$ 123,065$ & 47.209 & s 788,421 & 0.212 & 0.63 & 38.571 & 3.446 & 12.0 \\
\hline 3 & 5 & 3 & 50 & 35 & 20 & \$ 141.585 & 45.912 & $\$ 788,672$ & 0.212 & 0.63 & 36.825 & 3.180 & 12.0 \\
\hline 图 & 6 & 3 & 51 & 20 & 20 & s 124,732 & 47,146 & s 789,211 & 0.212 & 0.63 & 38.275 & 3.420 & 12.0 \\
\hline 国 & g & 3 & 50 & 25 & 20 & $\$ 135,753$ & 46.374 & $\$ 789.344$ & 0.213 & 0.64 & 36.681 & 3.265 & 12.0 \\
\hline 国 & 9 & 3 & 50 & 20 & 20 & \$ 129.503 & 46,832 & S 789,546 & 0.213 & 0.64 & 37,302 & 3,370 & 12.0 \\
\hline 国圆 & 5 & 3 & 51 & 30 & 20 & \$ 135,565 & 46,407 & s 789.618 & 0.213 & 0.63 & 37.458 & 3.242 & 12.0 \\
\hline 중 & 5 & 3 & 50 & 10 & 20 & $\$ 110,335$ & 48,272 & \$ 790.679 & 0.213 & 0.62 & 39,870 & 3.779 & 12.0 \\
\hline 图 & 6 & 3 & 50 & 35 & 20 & s 143,252 & 45.942 & s 790.757 & 0.213 & 0.64 & 36.605 & 3.171 & 12.0 \\
\hline 図 & 6 & 3 & 51 & 30 & 20 & $\$ 137,232$ & 46,427 & \$ 791,573 & 0.213 & 0.64 & 37,230 & 3.231 & 12.0 \\
\hline 园 & 5 & 3 & 50 & 35 & 30 & $\$ 147,585$ & 45,742 & \$ 792,266 & 0.213 & 0.62 & 36.734 & 2.910 & 11.5 \\
\hline 目图 & 6 & 3 & 50 & 10 & 20 & $\$ 112,002$ & 48.312 & $\$ 792.908$ & 0.213 & 0.63 & 39.671 & 3.765 & 12.0 \\
\hline 菏国 & 10 & 3 & 50 & 25 & 20 & \$ 137,420 & 46.521 & s 793.082 & 0.214 & 0.64 & 36,576 & 3.267 & 12.0 \\
\hline 일 & 5 & 3 & 51 & 35 & 20 & \$ 141,815 & 46.212 & S 793.128 & 0.214 & 0.63 & 37.071 & 3.178 & 12.0 \\
\hline & 10 & 3 & 50 & 20 & 20 & $\$ 131.170$ & 46.970 & \$ 793,167 & 0.214 & 0.64 & 37.189 & 3.371 & 12.0 \\
\hline$=0$ & 5 & 3 & 50 & 40 & 20 & $\$ 147,835$ & 45,851 & $\$ 794,052$ & 0.214 & 0.64 & 36.556 & 3.135 & 12.0 \\
\hline 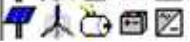 & 9 & 3 & 51 & 25 & 20 & $\$ 135,983$ & 46.713 & $\$ 794,347$ & 0.214 & 0.64 & 36.963 & 3.266 & 12.0 \\
\hline
\end{tabular}

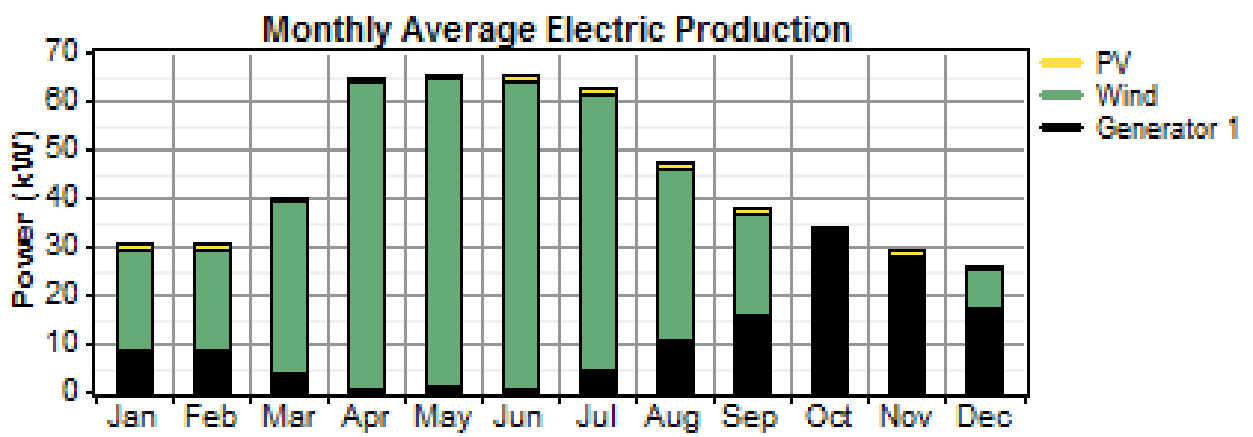

Figure 13. Monthly electricity productions for PV, Wind and Generator based system.

According to the optimization results, the optimal combination of the PV, diesel and Wind system have a $5 \mathrm{~kW}$ PV-Array, 25 Surrette 6CS25P Batteries, 20kW Inverter and a $20 \mathrm{~kW}$ Rectifier with a dispatch strategy of load following. Details of this configuration are shown in Table 7. The total NPC, operating cost and COE for such a system are Rs
43836300, Rs 2773620 and Rs 12.6/kWh, respectively.

As we know that for PV, diesel and Grid based system, Generator and batteries have a very important role as it is the only backup power component. Technical details of the battery for best suited configuration are shown in Table 7 .

Table 7. Technical \& Cost details of the best suited configuration for PV, diesel and Grid based system with batteries.

\begin{tabular}{lllllll}
\hline Cost summary & \multicolumn{3}{l}{ System Architecture } & Electrical & & \\
\hline Total net present cost & Rs 43836300 & PV Array & $5 \mathrm{~kW}$ & Component & Production & $(\mathrm{kWh} / \mathrm{yr})$ \\
Levelized cost of energy & Rs $12.6 / \mathrm{kWh}$ & Battery & 25 Surrette $6 \mathrm{CS} 25 \mathrm{P}$ & & & Fraction \\
Operating cost & Rs $2773620 / \mathrm{yr}$ & Wind & $75 \mathrm{~kW}$ & PV Array & 8,750 & $2 \%$ \\
Reliability & $100 \%$ & Generator & $50 \mathrm{~kW}$ & Diesel & 97,164 & $25 \%$ \\
& & Inverter & $20 \mathrm{~kW}$ & Wind turbine & 284,212 & $73 \%$ \\
& & Rectifier & $20 \mathrm{~kW}$ & Total & 390,126 & $100 \%$ \\
\hline
\end{tabular}


From Table 7 we can see that the total amount of generation of electricity for this configuration is $126581 \mathrm{kWh} / \mathrm{yr}$ more than the requirement which is i.e. extra electricity will able to sell to grid.

Emissions for PV, Diesel and Wind Turbine Connected System

As PV, diesel and Wind based system with batteries is used for the power generation, there will be pollutant emissions for this system configuration only from the generator which is less in compare to the only generated connected system.

Table 8. GHG \& emissions recorded from the HOMER analysis for PV, Wind and diesel based system.

\begin{tabular}{|c|c|}
\hline Pollutant & Emissions (kg/yr) \\
\hline Carbon dioxide & 98,800 \\
\hline Carbon monoxide & 244 \\
\hline Unburned hydrocarbons & 27 \\
\hline Particulate matter & 18.4 \\
\hline Sulfur dioxide & 198 \\
\hline Nitrogen oxides & 2,176 \\
\hline
\end{tabular}

Figure 5.12 shows the Wind and grid connected system configuration as designed in Homer simulation software.

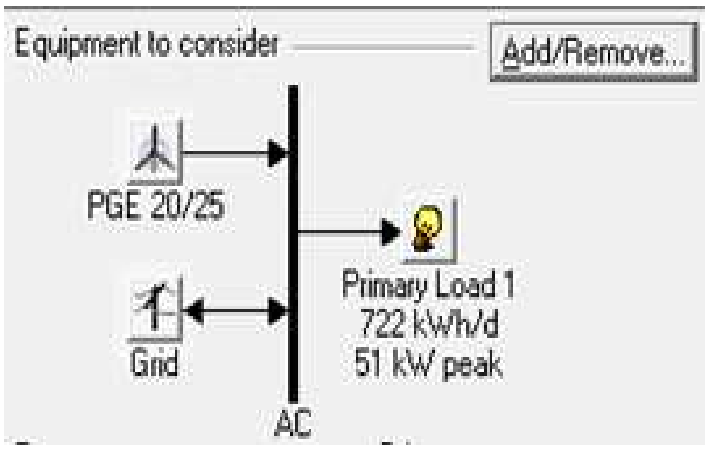

Figure 14. Wind and Grid connected system configuration.

Figure 14 shows the HOMER output results ordered from lowest NPC for adding the PV generation system to the simulation. HOMER uses the total NPC as its main selection tools.

\subsection{Wind and Grid Connected System}

\begin{tabular}{|c|c|c|c|c|c|c|c|c|}
\hline Senstivity Resut & Optimiz & ion Results & & & & & & \\
\hline \multicolumn{9}{|c|}{ Senstivity variables } \\
\hline \multicolumn{2}{|c|}{ Min. Ren Fraction $(\%) 0$} & $\nabla$ & & & & & & \\
\hline \multicolumn{9}{|c|}{ Double click on a system below for simulation results. } \\
\hline $1 \wedge^{\text {PGE25 }}$ & $\begin{array}{l}\text { Gid } \\
(\mathrm{kW})\end{array}$ & $\begin{array}{l}\text { Initial } \\
\text { Capital }\end{array}$ & $\begin{array}{l}\text { Operating } \\
\text { Cost }(\$ / y r)\end{array}$ & $\begin{array}{l}\text { Total } \\
\text { NPC }\end{array}$ & $\left.\mid \begin{array}{c}\mathrm{COE} \\
(\$ / \mathrm{kWh})\end{array}\right]$ & $\begin{array}{c}\text { Net Purchases } \\
(\mathrm{kWh} / \mathrm{yr})\end{array}$ & $\begin{array}{l}\text { Ren. } \\
\text { Frac. } \\
\end{array}$ & \begin{tabular}{|l|} 
Capacty \\
Shortage \\
\end{tabular} \\
\hline$\frac{1}{3}$ & 51 & $\$ 66.000$ & 10,476 & $\$ 213.649$ & 0.039 & 20665 & 0.74 & 0.00 \\
\hline 2 & 51 & $\$ 44,000$ & 16,183 & $\$ 272,075$ & 0.063 & 74,055 & 0.62 & 0.00 \\
\hline 12 & 51 & $\$ 22,000$ & 24,647 & $\$ 369,367$ & 0.099 & 168.793 & 0.36 & 0.00 \\
\hline
\end{tabular}

Figure 15. Optimization results for Wind and Grid based system.

Figure 15 shows the optimization results of Wind and grid connected system given by the HOMER. This system has a Wind fraction of $74 \%$ with a grid fraction of $26 \%$. For the optimal alternative system, the Wind turbine size is $75 \mathrm{~kW}$ and Grid is $51 \mathrm{~kW}$. Details of this configuration are shown in Table 9 The total NPC, Initial Capital cost and COE for such a hybrid system are Rs 30588300, Rs 2609520 and Rs $8.22 / \mathrm{kWh}$, respectively.

Table 9. Technical \& Cost details of the best suited configuration for Wind and Grid based system.

\begin{tabular}{|c|c|c|c|c|c|c|}
\hline Cost & summary & System & Architecture & & Electrical & \\
\hline Total net present cost & Rs 12818640 & Wind & $75 \mathrm{~kW}$ & Component & Production & Fraction \\
\hline Levelized cost of energy & Rs $2.34 / \mathrm{kWh}$ & Grid & $51 \mathrm{~kW}$ & & $\mathrm{kWh} / \mathrm{yr}$ & \\
\hline \multirow[t]{3}{*}{ Operating cost } & Rs 628560/yr & Dispatch Strategy & Load Following & Wind turbine & 284,212 & $74 \%$ \\
\hline & & Reliability & $100 \%$ & Grid & 100,359 & $26 \%$ \\
\hline & & & & Total & 384,572 & $100 \%$ \\
\hline
\end{tabular}

From Table 9 we can see that the total amount of generation of electricity for this configuration is more than the requirement which is $121,025 \mathrm{kWh} / \mathrm{yr}$ i.e. extra electricity will able to sell to grid and also there is no capacity shortage. 


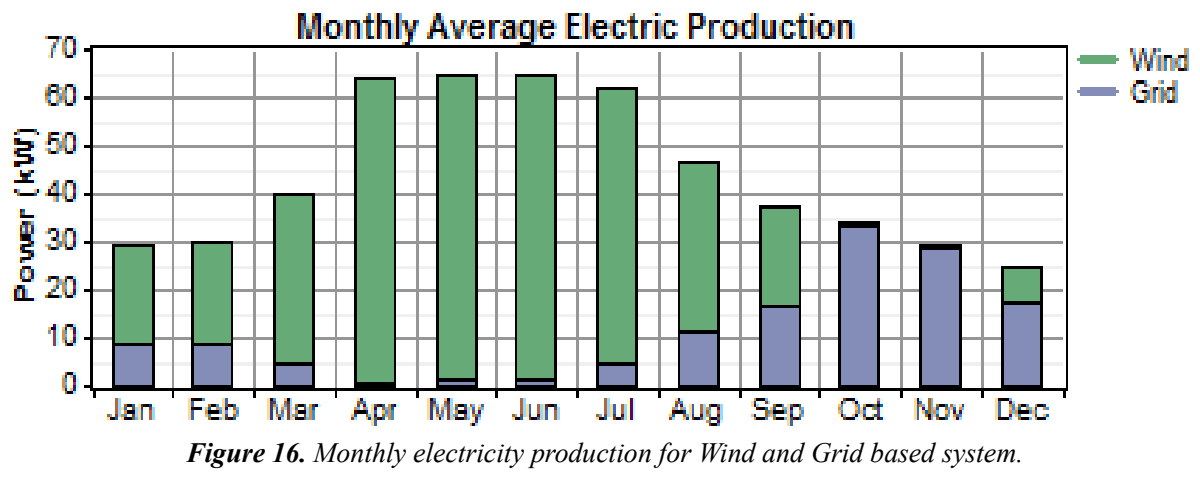

Figure 16 shows the monthly distribution of the electricity produced in $\mathrm{kW}$ by the Wind turbine and grid. There is excess electricity production but capacity shortage is also in this configuration.

Emissions for Wind and Grid Connected System

As Wind and Grid based system is used for the power generation, there will be no pollutant emissions for this system configuration from Wind system and the emission is only because of the Grid connection.

Table 10. GHG \& emissions recorded from the HOMER analysis for Wind and Grid based system.

\begin{tabular}{ll}
\hline Pollutant & Emissions $(\mathbf{k g} / \mathbf{y r})$ \\
\hline Carbon dioxide & $-13,061$ \\
Carbon monoxide & 0 \\
Unburned hydrocarbons & 0 \\
Particulate matter & 0 \\
Sulfur dioxide & -56.6 \\
Nitrogen oxides & -27.7 \\
\hline
\end{tabular}

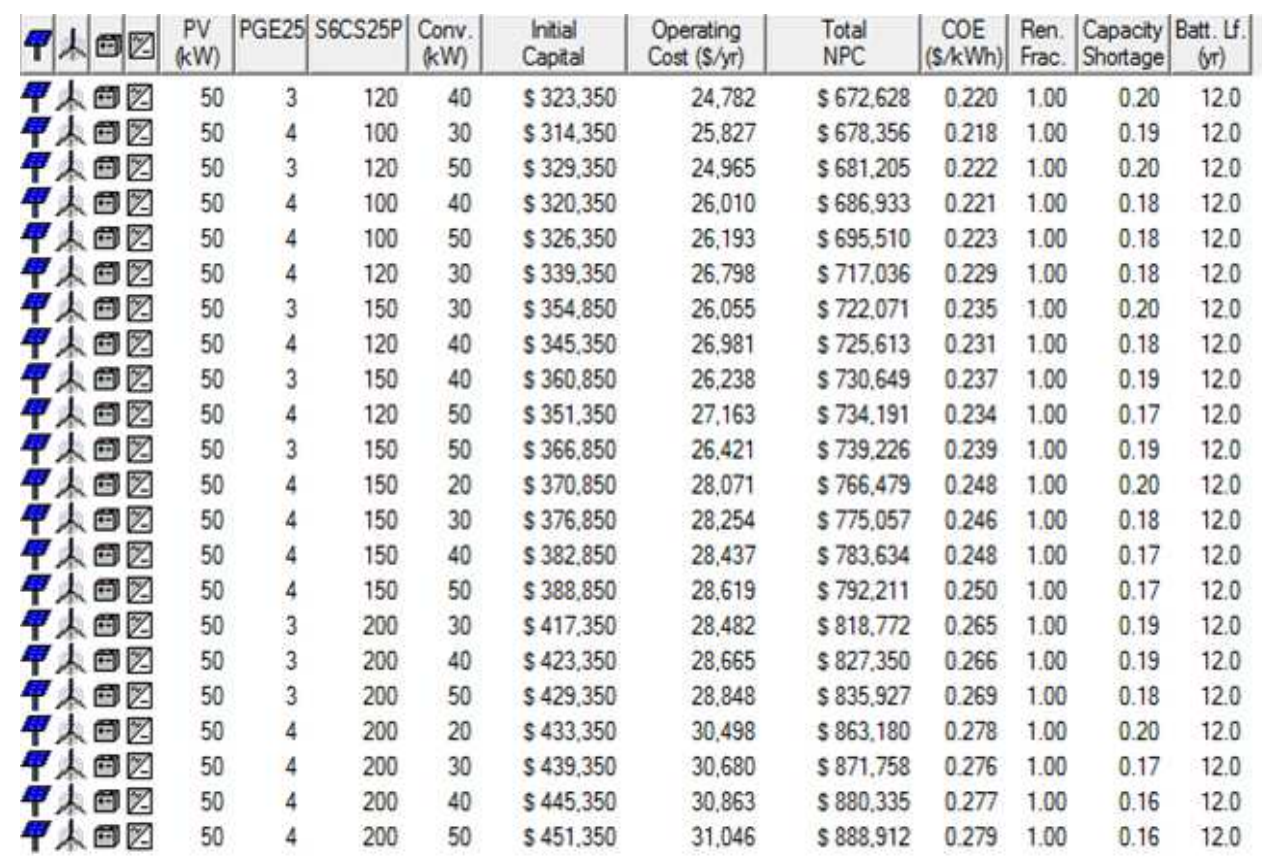

\subsection{PV and Wind Connected System}

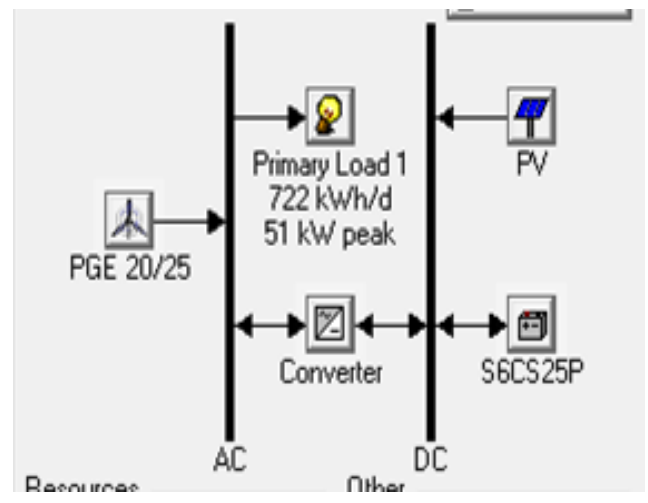

Figure 17. PV and Wind connected system configuration.

Figure 17 shows the PV and Wind connected system configuration as designed in Homer simulation software.

Figure 18 shows the HOMER output results ordered from lowest NPC for adding the PV generation system to the simulation. HOMER uses the total NPC as its main selection tool.

Figure 18. Optimization results for $P V$ and Wind based system. 
Figure 18 shows the optimization results of PV and Wind connected system with batteries backup given by the HOMER. This system has a PV fraction of $19 \%$ and Wind fraction of $81 \%$. For the optimal alternative system, the PV array size is $50 \mathrm{~kW}$ and Wind turbine size is $100 \mathrm{~kW}$ and there is 100 no. of batteries for backup. There is capacity shortage of about $20 \%$ however the optimization result shows the excess electricity production due to the variation in climate in different seasons which is $230937 \mathrm{kWh} / \mathrm{yr}$. And the unmet load is $43240 \mathrm{kWh} / \mathrm{yr}$. The excess electricity will be able to sell to grid.

Details of this configuration are shown in Table 11. The total NPC, operating cost and Levelized cost of energy (COE) for such a hybrid system are Rs12818640, 628560 and Rs $2.34 / \mathrm{kWh}$, respectively.

Table 11. Technical \& Cost details of the best suited configuration for PV and Wind based system.

\begin{tabular}{|c|c|c|c|c|c|c|}
\hline Cost & summary & System & Architecture & & Electrical & \\
\hline Total net present cost & Rs 40701360 & PV array & $50 \mathrm{~kW}$ & Component & Production & Fraction \\
\hline Levelized cost of energy & Rs $13.8 / \mathrm{kWh}$ & Wind & $100 \mathrm{~kW}$ & & $\mathrm{kWh} / \mathrm{yr}$ & \\
\hline Operating cost & Rs $1549620 / y r$ & Dispatch Strategy & Load Following & PV array & 87,500 & $19 \%$ \\
\hline \multirow[t]{2}{*}{ Reliability } & $80 \%$ & Inverter & $40 \mathrm{~kW}$ & Wind turbine & 378,950 & $81 \%$ \\
\hline & & Rectifier & $40 \mathrm{~kW}$ & Total & 466,449 & $100 \%$ \\
\hline
\end{tabular}

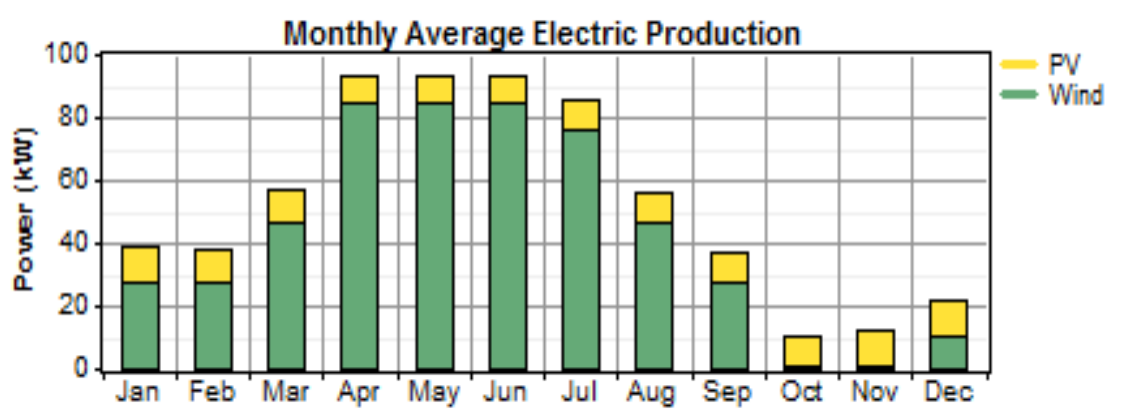

Figure 19. Monthly average electricity production for PV and Wind based system.

Figure 19 shows the monthly distribution of the electricity produced in $\mathrm{kW}$ by the SPV and Wind turbine. There is excess electricity production but capacity shortage is also in this configuration.

Emissions for PV and Wind turbine connected system

As Solar and Wind based system is used for the power generation, there will be no pollutant emissions for this system configuration because there is no use of diesel or coal Wind and Grid connected system which is good for the environment.

Table 12. GHG \& emissions recorded from the HOMER analysis for PV and Wind based system.

\begin{tabular}{ll}
\hline Pollutant & Emissions $(\mathbf{k g} / \mathbf{y r})$ \\
\hline Carbon dioxide & 0 \\
Carbon monoxide & 0 \\
Nitrogen oxides & 0 \\
\hline
\end{tabular}

\subsection{PV, Wind and Grid Connected System}

Figure 20 shows the PV, Wind and grid connected system configuration as designed in Homer simulation software.

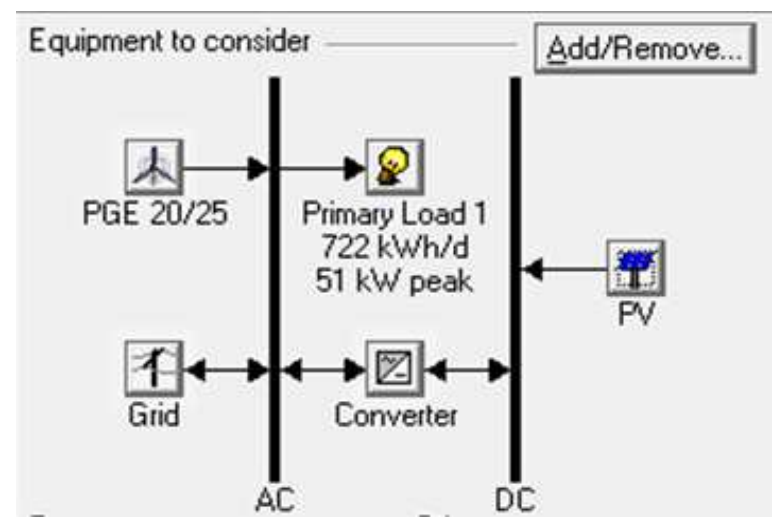

Figure 20. $P V$, Wind and Grid connected system configuration.

Figure 21 shows the HOMER output results ordered from lowest NPC for adding the PV generation system and Wind generation system to the simulation. HOMER uses the total NPC as its main selection tool.

Figure 21 shows the optimization results of PV, Wind and Grid connected system given by the HOMER. This system has a PV fraction of $14 \%$ and Wind fraction of $37 \%$ and Grid fraction of $49 \%$. For the optimal alternative system, the PV array size is $20 \mathrm{~kW}$ and Wind turbine size is $25 \mathrm{~kW}$ and Grid size is $25 \mathrm{~kW}$. There is capacity shortage of $10 \%$ which is about $26,467 \mathrm{kWh} / \mathrm{yr}$. And the unmet load is $17,847 \mathrm{kWh} / \mathrm{yr}$. 
Details of this configuration are shown in Table 13.The total NPC, operating cost and Levelized cost of energy (COE) for such a hybrid system are Rs23573760, 1385940 and Rs $6.6 / \mathrm{kWh}$, respectively.

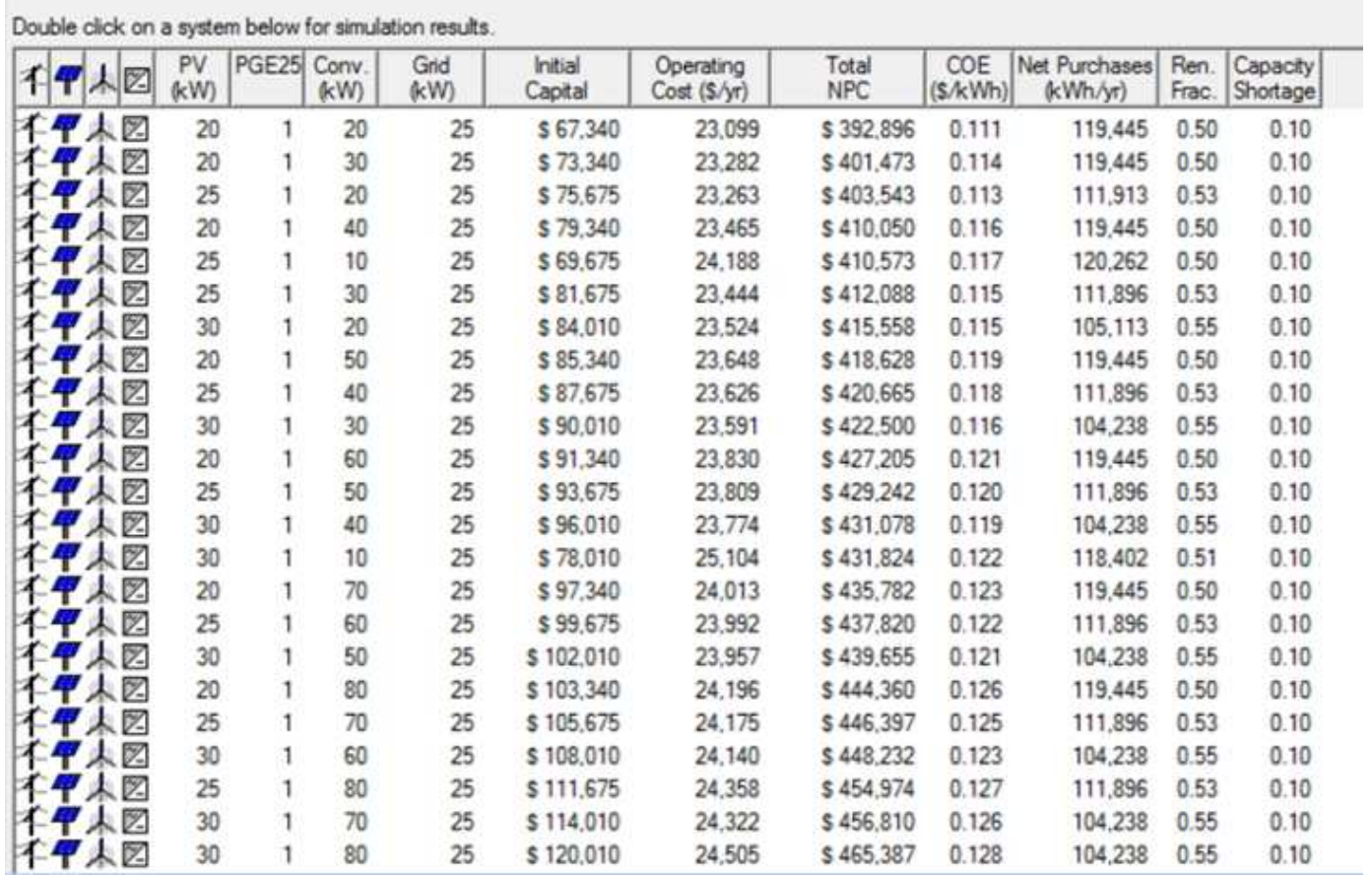

Figure 21. Optimization results for PV, Wind and Grid based system.

Table 13. Technical \& Cost details of the best suited configuration for PV. Wind and Grid based system.

\begin{tabular}{|c|c|c|c|c|c|c|}
\hline \multicolumn{2}{|l|}{ Cost summary } & \multicolumn{2}{|c|}{ System Architecture } & \multicolumn{3}{|l|}{ Electrical } \\
\hline \multirow{3}{*}{$\begin{array}{l}\text { Total net present cost } \\
\text { Levelized cost of energy }\end{array}$} & Rs 23573760 & PV Array & $20 \mathrm{~kW}$ & \multirow{2}{*}{ Component } & Production & \multirow{2}{*}{ Fraction } \\
\hline & Rs 6.6/kWh & Wind turbine & $25 \mathrm{~kW}$ & & $(\mathrm{kWh} / \mathrm{yr})$ & \\
\hline & & Grid & $25 \mathrm{~kW}$ & PV array & 35,000 & $14 \%$ \\
\hline \multirow{2}{*}{ Operating cost } & & Rectifier & $20 \mathrm{~kW}$ & Grid purchases & 124,366 & $49 \%$ \\
\hline & & Reliability & $90 \%$ & Total & 254,104 & $100 \%$ \\
\hline
\end{tabular}

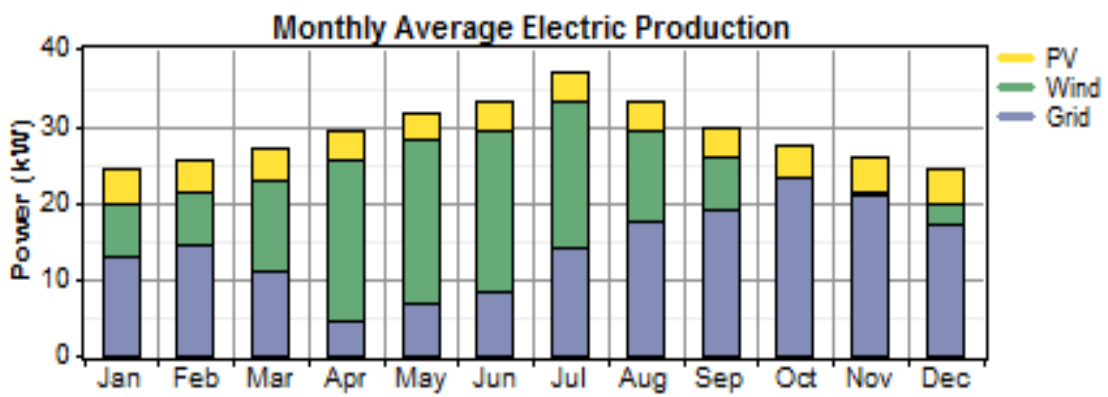

Figure 22. Monthly average electricity production for PV, Wind and Grid based system.

Figure 22 shows the monthly distribution of the electricity produced in $\mathrm{kW}$ by the SPV, Wind turbine and grid. There is excess electricity production but capacity shortage is also in this configuration.

Emissions for PV, Wind turbine and Grid connected system

As Solar and Wind based system is used for the power generation, there will be no pollutant emissions from the PV and Wind turbine in this system configuration but there is use of diesel or coal in Grid electricity generation which emits green house gases this is shown in Table 14.
Table 14. GHG \& emissions recorded from the HOMER analysis for PV, Wind and Grid based system.

\begin{tabular}{ll}
\hline Pollutant & Emissions $(\mathbf{k g} / \mathbf{y r})$ \\
\hline Carbon dioxide & 75,490 \\
Carbon monoxide & 0 \\
Unburned hydrocarbons & 0 \\
Particulate matter & 0 \\
Sulfur dioxide & 327 \\
Nitrogen oxides & 160 \\
\hline
\end{tabular}




\subsection{Wind, Diesel and Grid Connected System}

Figure 23 shows the Wind, Diesel and grid connected system configuration as designed in Homer simulation software.

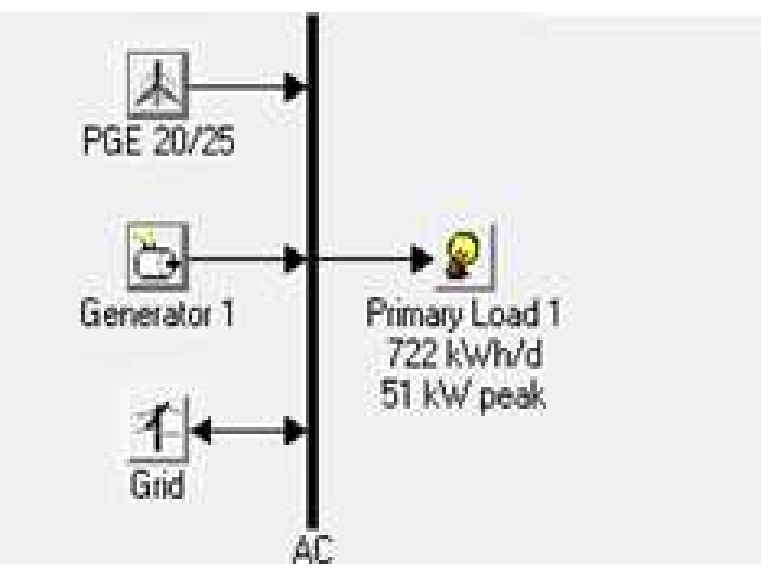

Figure 23. Wind, Diesel and Grid connected system configuration.

Figure 24 shows the HOMER output results ordered from lowest NPC for adding the Wind generation system and Diesel generator to the simulation. HOMER uses the total NPC as its main selection tool.

\begin{tabular}{|c|c|c|c|c|c|c|c|c|c|c|c|}
\hline & & $\begin{array}{l}\text { Label } \\
\text { KWM }\end{array}$ & $\begin{array}{l}\text { Gnd } \\
\mathrm{KW}\end{array}$ & $\begin{array}{l}\text { hatal } \\
\text { Copotal }\end{array}$ & $\begin{array}{l}\text { Operdith } \\
\cos (\text { s sys) }\end{array}$ & $\begin{array}{l}\text { Total } \\
\text { NPC }\end{array}$ & \begin{tabular}{|c|}
$\operatorname{COE}$ \\
$(S / K W h)$
\end{tabular} & \begin{tabular}{|c|} 
Net Puchasees \\
(kWhyr)
\end{tabular} & $\begin{array}{l}\text { Ren. } \\
\text { Frac. }\end{array}$ & $\begin{array}{l}\text { Desel } \\
(4)\end{array}$ & $\begin{array}{l}\text { Labed } \\
(n s)\end{array}$ \\
\hline & 2 & 25 & 25 & $\$ 49,750$ & 24.200 & $\$ 390,820$ & 0.090 & 49.712 & 0.62 & 11,121 & 2,442 \\
\hline & 2 & 30 & 25 & $\$ 50,900$ & 25,571 & $\$ 411,299$ & 0.095 & 47,495 & 0.62 & 12,652 & 2,442 \\
\hline $1<0$ & 1 & 25 & 25 & $\$ 27,750$ & 35.307 & $\$ 525,371$ & 0.141 & 136.113 & 0.36 & 14,754 & 3.292 \\
\hline $1<0$ & 1 & 30 & 25 & $\$ 28.900$ & 37,174 & $\$ 552.831$ & 0.148 & 132.924 & 0.36 & 16.868 & 3.292 \\
\hline
\end{tabular}

Figure 24. Optimization results for Wind, Diesel and Grid based system.

Figure 24 shows the optimization results of Wind, Diesel and Grid connected system given by the HOMER. This system has a Wind turbine fraction of $62 \%$, Diesel fraction of $8 \%$ and Grid purchases fraction of $30 \%$. For the optimal alternative system, Wind turbine size is $50 \mathrm{~kW}$, generator size is $25 \mathrm{~kW}$ and Grid size is $25 \mathrm{~kW}$. There is almost no capacity shortage.

Details of this configuration are shown in Table 15. The total NPC, operating cost and Levelized cost of energy (COE) for such a hybrid system are Rs23449200, 1542000 and Rs $5.4 / \mathrm{kWh}$, respectively.

Table 15. Technical \& Cost details of the best suited configuration for Wind, Diesel and Grid based system.

\begin{tabular}{|c|c|c|c|c|c|c|}
\hline \multicolumn{2}{|l|}{ Cost summary } & \multicolumn{2}{|c|}{ System Architecture } & \multicolumn{3}{|l|}{ Electrical } \\
\hline Total net present cost & Rs 23449200 & Wind turbine & $50 \mathrm{~kW}$ & Component & Production & \\
\hline \multirow[t]{2}{*}{ Levelized cost of energy } & Rs $5.4 / \mathrm{kWh}$ & Diesel & $25 \mathrm{~kW}$ & Component & $(\mathrm{kWh} / \mathrm{yr})$ & Fraction \\
\hline & & & & Wind turbine & 189,475 & $62 \%$ \\
\hline \multirow[t]{3}{*}{ Operating cost } & Rs $1542000 / \mathrm{yr}$ & Grid & $25 \mathrm{~kW}$ & Diesel & 24,949 & $8 \%$ \\
\hline & & Reliability & $100 \%$ & Grid purchases & 92,957 & $30 \%$ \\
\hline & & & & Total & 307,381 & $100 \%$ \\
\hline
\end{tabular}

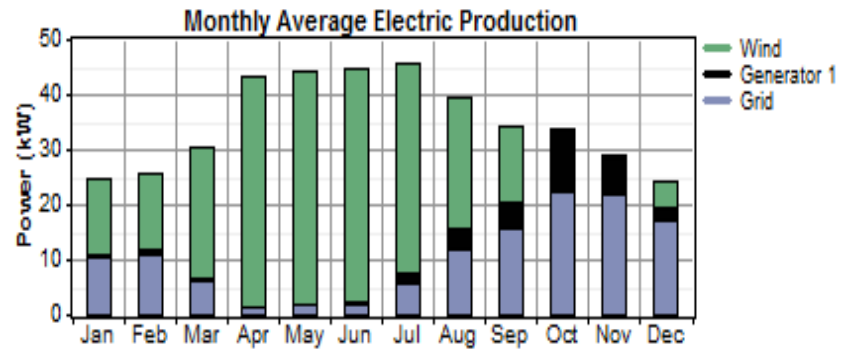

Figure 25. Monthly average electricity productions for Wind, Diesel and Grid based system.

Figure 25 shows the monthly distribution of the electricity produced in $\mathrm{kW}$ by the Wind turbine generator, Diesel and grid. There is excess electricity production of about $43,245 \mathrm{kWh} / \mathrm{yr}$ which will be able to sell to Grid and no capacity shortage in this configuration.

Emissions for PV, diesel and Grid connected system

As Wind and Grid based system is used for the power generation, there will be no pollutant emissions for this system configuration from PV system and the emission is only because of the Grid connection and is shown in Table 16.
Table 16. GHG \& emissions recorded from the HOMER analysis for Wind, Diesel and Grid based system.

\begin{tabular}{ll}
\hline Pollutant & Emissions $(\mathbf{k g} / \mathbf{y r})$ \\
\hline Carbon dioxide & 60,704 \\
Carbon monoxide & 72.3 \\
Unburned hydrocarbons & 8.01 \\
Particulate matter & 5.45 \\
Sulfur dioxide & 195 \\
Nitrogen oxides & 712 \\
\hline
\end{tabular}

\section{Results and Discussion}

After analyzing all the system models, Wind and Grid connected system is found to be more economical with lowest cost of energy of Rs $2.34 / \mathrm{kWh}$ and $100 \%$ reliable for the selected site. At present the cost of energy for the grid connected system is Rs $7.5 / \mathrm{kWh}$ in India, which it is expected to increase with time. At the same time the $\mathrm{CO}_{2}$ emissions is maximum for the grid connected system which can be reduced by adding the wind energy with the grid 
connected system with much influenced in the cost of energy. By adding the alternative sources, we can overcome the scheduled power cut too. Internal rate of return of wind and Grid connected system is $4.5 \%$ and NPC for wind and grid connected system is Rs.12818640. and payback period is about 5 years, which attract the investors and is also good from economical point of view. However the cost of energy of other systems is high. For PV and Grid connected system, the total NPC, initial capital cost and COE for such a hybrid system are Rs 30588300, Rs 2609520 and Rs 8.22/kWh, respectively. Internal rate of return is $10.35 \%$ and payback period is about 1.2 years. For PV, Diesel and Grid connected system, the total NPC, operating cost and Levelized cost of energy (COE) for such a hybrid system are Rs 56385240, 3803820 and Rs $15.18 / \mathrm{kWh}$ respectively, internal rate of return is $11.2 \%$ and payback period is about 2 years. For PV, Wind and Diesel connected system, The total NPC, operating cost and COE for such a system are Rs 43836300, Rs
2773620 and Rs 12.6/kWh, respectively Internal rate of return $7.2 \%$ and payback period is about 2.3 years. For PV and Wind connected system, the total NPC, operating cost and Levelized cost of energy (COE) for such a hybrid system are Rs12818640, 628560 and Rs $2.34 / \mathrm{kWh}$ respectively, internal rate of return $3.15 \%$ and payback period is about 6.5 years. For PV, Wind and Grid connected system, The total NPC, operating cost and Levelized cost of energy (COE) for such a hybrid system are Rs23573760, 1385940 and Rs $6.6 / \mathrm{kWh}$ respectively. Internal rate of return is $6.4 \%$ and payback period is about 3 years. For Wind, Diesel and Grid connected system, the total NPC, operating cost and Levelized cost of energy (COE) for such a hybrid system are Rs 23449200, 1542000 and Rs 5.4/kWh, respectively Internal rate of return $8 \%$ and payback period is about 2 years. Carbon emission is also more in other systems which causes green house effect. Table 17 shows the economical comparison between different combinations of hybrid system.

Table 17. Techno-Economical comparison between different combinations of hybrid system.

\begin{tabular}{|c|c|c|c|c|c|}
\hline \multirow{2}{*}{ S. No } & \multicolumn{2}{|c|}{ Total system size $=51 \mathrm{~kW}$} & \multicolumn{3}{|l|}{ SYSTEMS } \\
\hline & $(\mathbf{P v}+\mathbf{w}+\mathbf{d})$ & $(\mathbf{P v}+\mathrm{g})$ & $(w+g)$ & $(\mathbf{P v}+\mathbf{w})$ & $(\mathrm{Pv}+\mathrm{w}+\mathrm{g})$ \\
\hline \multirow{3}{*}{ System fraction } & $\mathrm{PV}=2 \%$ & \multirow{3}{*}{$\begin{array}{l}\mathrm{PV}=4 \% \\
\mathrm{G}=96 \%\end{array}$} & \multirow{3}{*}{$\begin{array}{l}W=74 \% \\
G=26 \%\end{array}$} & \multirow{3}{*}{$\begin{array}{l}\mathrm{PV}=19 \% \\
\mathrm{~W}=81 \%\end{array}$} & $\mathrm{PV}=14 \%$ \\
\hline & $\mathrm{W}=73 \%$ & & & & $\mathrm{~W}=37 \%$ \\
\hline & $\mathrm{D}=25 \%$ & & & & $\mathrm{G}=49$ \\
\hline \multirow{3}{*}{ System Architecture } & $\mathrm{PV}=5 \mathrm{kw}$ & \multirow{3}{*}{$\begin{array}{l}\mathrm{PV}=5 \mathrm{kw} \\
\mathrm{G}=51 \mathrm{kw}\end{array}$} & \multirow{3}{*}{$\begin{array}{l}\mathrm{WT}=75 \mathrm{kw} \\
\mathrm{G}=51 \mathrm{kw}\end{array}$} & \multirow{3}{*}{$\begin{array}{l}\mathrm{PV}=50 \mathrm{kw} \\
\mathrm{WT}=100 \mathrm{kw}\end{array}$} & $\mathrm{PV}=20 \mathrm{kw}$ \\
\hline & $\mathrm{WT}=75 \mathrm{kw}$ & & & & $\mathrm{WT}=25 \mathrm{kw}$ \\
\hline & Gen $=50 \mathrm{kw}$ & & & & $\mathrm{G}=25 \mathrm{kw}$ \\
\hline C.O.E(Rs.) & 12.6 & 8.22 & 2.34 & 13.8 & 6.6 \\
\hline I.R.R (\%) & 7.2 & 10.35 & 4.5 & 3.15 & 6.4 \\
\hline N.P.C (Rs.) & 43836300 & 30588300 & 12818640 & 40701360 & 23573760 \\
\hline Annual Cost (Rs) & 3323160 & 2170320 & 909540 & 2887860 & 1672620 \\
\hline Payback Period (years) & 2.3 & 1.2 & 5 & 6.5 & 3 \\
\hline Operating cost (Rs./yr) & 2773620 & 2114940 & 628560 & 1549620 & 1385940 \\
\hline Reliability (\%) & 100 & 93 & 100 & 80 & 90 \\
\hline
\end{tabular}

\section{Conclusion}

This study presents the techno-economic feasibility analysis of hybrid systems for decentralized power generation in India. The results of the study shows that the remote sites of the type considered in this work are prospective locations for the installation of hybrid renewable energy systems based on solar and wind energy. HOMER was used for the analysis, and viability was determined on the basis of internal rate of return, net present cost and cost of energy. The simulation results shows that Wind and Grid connected system is found to be more economical amongst all the configurations considered in this study with the cost of energy of Rs $2.34 / \mathrm{kWh}$ with $100 \%$ reliability. At present time the cost of energy for the grid connected system is Rs $7.5 / \mathrm{kWh}$, which is expected to increase with time. At the same time the $\mathrm{CO}_{2}$ emissions is maximum for the grid connected system which can be reduced by adding the Wind energy with the grid connected system with much influenced in the cost of energy. By adding the alternative sources, we can overcome the scheduled power cut too.

Successful implementation of large scale hybrid renewable energy systems requires devising suitable policy measures after considerations of local support, institutional barriers and other social factors. This necessitates joint efforts from policy makers and modeling experts for clear representation of the energy problem and effective implementation of the solutions as there are certain hindrances for the implementation of hybrid renewable energy systems in countries like India for example lack of technical support in case of repair and maintenance, lack of finances and subsidies for creation of projects in rural areas, lack of policy and regulations for the promotion of both off grid and grid connected hybrid renewable energy systems. This calls for the need to promote hybrid renewable energy systems, which can cater to local communities in much effective manner. Apart from providing better quality of life to rural communities, it could have significant effect in the improvement of rural economy.

In view of the above, this work promotes hybrid renewable energy systems for remote places of the type considered in this work as the most cost effective solution. This would involve accelerating the overall development of the under developed areas with a number of programs like providing electricity, entrepreneurship development and employment generation opportunities. 


\section{References}

[1] Al-Badi A. H. , AL-Toobi M., AL-Harthy S., Al-Hosni Z. and AL-Harthy A. "Hybrid systems for decentralized power generation in Oman". International Journal of sustainable energy, Vol. 31(6), pp. 411-421, 2012.

[2] Balamurugan, P., S. Ashok, and T.L. Jose. "Optimal operation of biomass /wind/ PV hybrid energy system for rural areas" International Journal of Green Energy, Vol. 6(1), pp. 104-16, 2009.

[3] Kumaravel, S. and S. Ashok. "An optimal stand-alone biomass/solar-PV/pico-hydel hybrid energy system for remote rural area electrification of isolated village in western-ghats region of India" International Journal of Green Energy, Vol. 9(5), pp. 398-408, 2012.

[4] W. D. Kellogg, M. H. Nehrir, G. Venkataramanan and V. Gerez, "Generation Unit Sizing and Cost Analysis for StandAlone Wind, Photovoltaic, and Hybrid Wind/PV System" IEEE Transactions on Energy Conversion Vol. 13, pp.70-76, 1998.

[5] Ali Naci Celik, "Techno-economic analysis of autonomous PV-wind hybrid energy systems using different sizing methods" Energy Conversion and Management. Vol. 44, pp. 1951-1968, 2003.
[6] Ngan MS, Tan CW, "Assessment of Economic Viability for PV/Wind/Diesel Hybrid Energy System in Southern Peninsular Malaysia", Renewable and Sustainable Energy Reviews, Vol. 16, pp. 634- 647, 2011.

[7] Karakoulidis, K. et al., Techno-Economic Analysis of A StandAlone Hybrid Photovoltaic-Diesel-Battery-Fuel Cell Power System, Renewable Energy, Vol. 36, pp. 2238-2244, 2011.

[8] Bahtiyar Dursun, Cihan Gokcol, Ilhan Umut ${ }^{3}$, Erdem Ucar ${ }^{3}$ and Sureyya Kocabey, 2013, Techno-Economic Evaluation of a Hybrid PV-WIND Power Generation System, taylor and francis International Journal of Green Energy, 10: 117-136.

[9] J.Dekker, M. Nthontho, S. Chawdhury, S.P. Chawdhury,2012, Economic analysis of PV/diesel hybrid systems in different climate zones of South Africa, Elsevier,

[10] Eyad S. Hrayshat, 2013, Techno-economic analysis of autonomous hybrid photovoltaic-diesel-battery system", Energy for Sustainable Development: 13,143-150.

[11] Majid Jamil, Sheeraz Kirmani and Himanshu Chatterjee, "Techno-economic viability of three different energysupplying options for remote area electrification in India," international journal of sustainable energy, Vol. 33, No. 2, pp. 470-482. 